\title{
Preliminary Evaluation of Graphite in the FMIT Test Cell
}

W. C. Morgan

March 1980

Prepared for

Hanford Engineering Development

Laboratory

Pacific Northwest Laboratory

Operated for the U.S. Department of Energy

by Battelle Memorial Institute 
NOTICE

This report was prepared as an account of work sponsored by the United States Government. Neither the United States nor the Department of Energy, nor any of their employees, nor any of their contractors, subcontractors, or their employees, makes any warranty, express or implied, or assumes any legal liability or responsibility for the accuracy, completeness or usefulness of any information, apparatus, product or process disclosed, or represents that its use would not infringe privately owned rights.

The views. opinions and conclusions contained in this report are those of the contractor and do not necessarily represent those of the United States Government or the United States Department of Energy.

\author{
PACIFIC NORTHWEST LABORATORY \\ operated by \\ BATTELLE \\ for the \\ UNITED STATES DEPARTMENT OF ENERGY \\ Under Contract DE-AC06-76RLO 1830
}
Printed in the United States of America Available from
National Technical Information Service United States Department of Commerce 5285 Port Royal Road
Springfield, Virginia 22151

Price: Printed Copy \$ - Microfiche $\$ 3.00$

NTIS

- Pages Selling Price

001-025 $\quad \$ 4.00$

026-050 $\$ 4.50$

$051-075 \quad 55.25$

$076-100 \div \quad \$ 6.00$

$101-125 \quad \$ 6.50$

$126-150 \quad \$ 7.25$

$151-175 \quad \$ 8.00$

$176.200 \quad \$ 9.00$

201-225 \$9.25

226-250 \$9.50

251-275 $\quad 510.75$

$276-300 \quad \$ 11.00$ 


\section{3}

PRELIMINARY EVALUATION OF GRAPHITE IN THE FMIT TEST CELL

W. C. Morgan

March 1980

Prepared for Hanford Engineering Development Laboratory under a related services agreement with the U.S. Department of Energy under Contract DE-AC06-76RLO 1830, Work Order No. A-32099

Pacific Northwest Laboratory Richland, Washington 99352 


\author{
W. C. Morgan
}

\title{
$\underline{\text { ABSTRACT }}$
}

A design for the Test Cell of the Fusion Materials Irradiation Test facility includes composite steel-graphite cooling/shielding panels. A graphite damage fluence of about $3.2 \times 10^{20} / \mathrm{cm}^{2}$ at about $80^{\circ} \mathrm{C}$ can be expected over 20 years of operation. This review defines the potential problem areas (stored energy and dimensional changes) and recommends approaches to avoid or alleviate those problems. It is concluded that the design is viable and that no insurmountable problems are likely to be encountered. 


\section{CONTENTS}

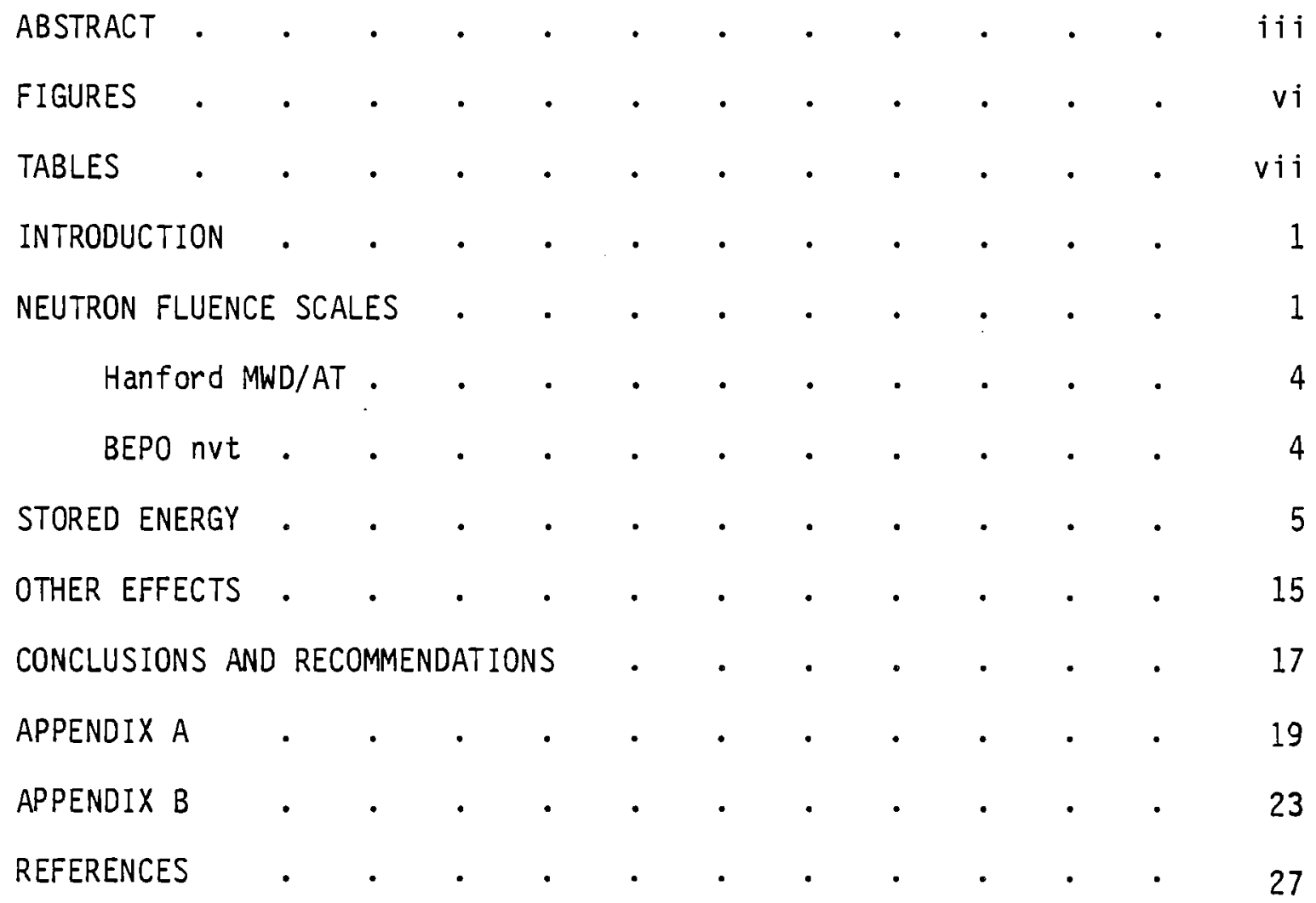




\section{FIGURES}

1 Total Stored Energy as a Function of Exposure and Irradiation Temperature $. \quad . \quad . \quad . \quad . \quad . \quad . \quad$.

2 Linear-Rise Curves of Stored Energy Release . $\quad$ • $\quad$. $\quad$. $\quad 7$

3 Energy Release from Irradiated Graphite . . . . 8

4 Calculated Rate of Release of Energy in a Linear Rise Experiment at $2^{\circ} \mathrm{C}$ per minute and $2^{\circ} \mathrm{C}$ per hour $. . . \quad . \quad . \quad 8$

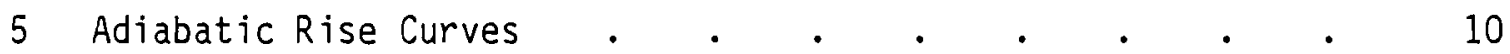

6 The Effect of Starting Temperature on Adiabatic Energy Release 10

7 Effect of Irradiation Temperature on the Starting Temperature to Give Standard Adiabatic Release Rate . . . . . . 11



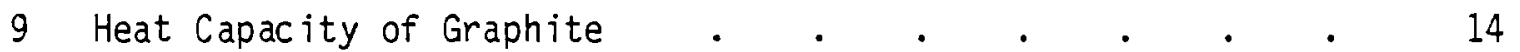

10 Effect of Pretreatment at $110^{\circ} \mathrm{C}$ on Linear-Rise Curves . 16

Ratio of Damage Fluence to Fluence of Neutrons with
Energy Greater Than $E_{1}$. $\quad . \quad$. 


\section{TABLES}

1 Relative Damage per Neutron . . . . . . . . 3



3235 f Fission Spectrum-Averaged Cross Sections . . . 20

4 Extrapolated Cross Sections . . . . . . . . . 21

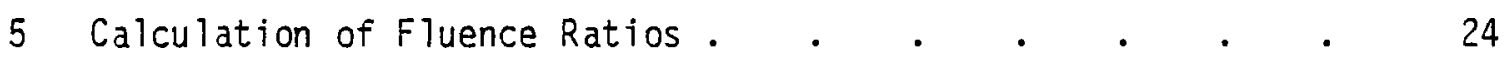





\section{INTRODUCTION}

Staff of the Ralph M. Parsons Co. have evaluated (1) possible combinations of materials for use as cooling/shielding panels in the test cell of the Fusion Materials Irradiation Test (FMIT) facility, and have recommended (with certain reservations) that the panels be composed of alternate layers of steel and graphite. The primary reservation, in regard to the use of this composite, is a concern over the possible consequences of a build-up of stored energy in the graphite panels.

The purpose of this report is to:

1) define the extent of the potential problem with stored energy,

2) define other potential problem areas associated with this use of graphite, and

3) recommend means of avoiding potential problems.

Most of the data on the behavior of graphite at low irradiation temperatures was accumulated during the 1940's and 1950's. Various irradiation exposure units were used in reporting the data, and many of these units have only a tenuous relationship to the actual damage (changes in properties) produced by the irradiation; therefore, it is necessary to reduce the reported exposure units to a common and meaningful scale.

\section{NEUTRON FLUENCE SCALES}

The internationally accepted neutron exposure unit, for comparing the damage produced in graphite irradiated in different neutron flux spectra, $(2-4)$ is the "Equivalent Fission Fluence for Damage in Graphite $\left(\Phi_{G}\right)$, which can be defined as follows: 


$$
\Phi_{G}=\frac{\int_{t_{1}}^{t_{2}} \int_{0}^{\infty} \Sigma_{d}(E) \phi(E, t) d E d t}{\int_{0}^{\infty} \Sigma_{d}(E) x(E) d E / \int_{0}^{\infty} x(E) d E}
$$

where

$$
\begin{aligned}
\phi(E, t) & =\text { absolute flux density spectrum at time } t \\
x(E) & ={ }^{235} U \text { fission spectrum } \\
\Sigma_{d}(E) & =\sigma_{S}(E) p(E) .
\end{aligned}
$$

where

$$
\begin{aligned}
& \sigma_{S}(E)=\text { scattering cross section of carbon } \\
& p(E)=\text { (Thompson and Wright }{ }^{(5)} \text { form of) the weighing function. }
\end{aligned}
$$

It is also useful to define another quantity, $\bar{\Sigma}_{f}$, the spectrum averaged atomic displacement cross section in a ${ }^{235} U$ fission spectrum:

$$
\bar{\Sigma}_{f}=\int_{0}^{\infty} \quad \Sigma_{d}(E) \quad X(E) d E / \int_{0}^{\infty} X(E) d E
$$

Although more recent forms of the damage cross section, $\Sigma_{d}(E)$, have been developed to obtain better comparisons between irradiations in fission-reactor and fusion-reactor spectra, $(6,7)$ the Thompson and Wright $(T-W)$ form of the weighting function will be used herein. Since only a few percent of the neutrons in the shield have energies greater than $1.0 \mathrm{MeV}$, the results which would be obtained using the other functions should be essentialiy identical to those obtained using the T-W form.

Table 1 lists the normalized neutron flux in different energy groups, at the front and rear faces of the steel/graphite shield composite, and the damage cross sections $(3)$ used to calculate $\Phi_{G}$. 
TABLE 1. Relative Damage per Neutron

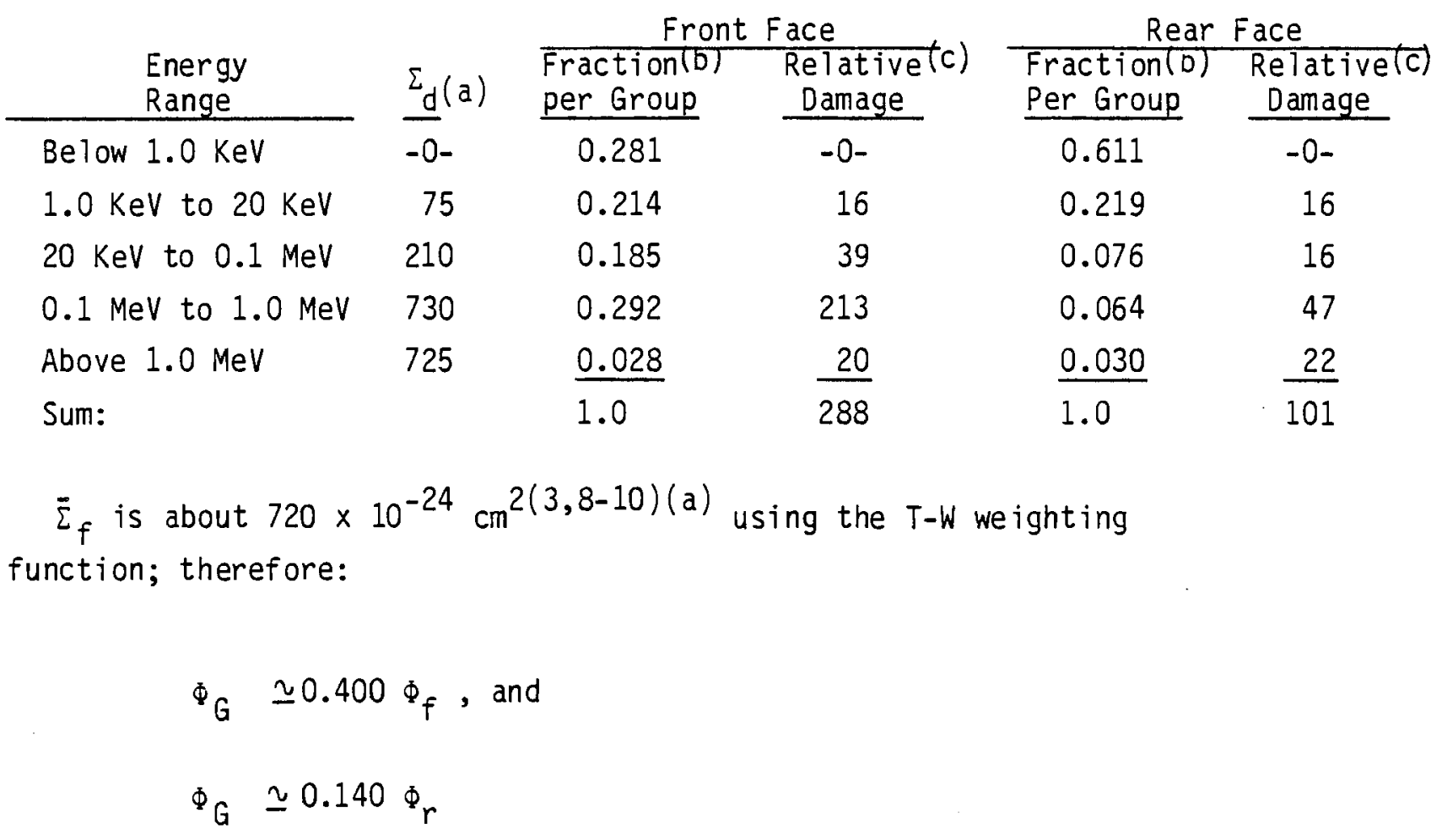

where $\Phi_{f}=$ total neutron fluence at the front of the composite region, and $\Phi_{r}=$ total neutron fluence at the rear face of the composite shield region.

Using a total neutron flux ${ }^{(b)}$ of $1.85 \times 10^{12} / \mathrm{cm}^{2} \mathrm{sec}$ at the front and $8.07 \times 10^{10} / \mathrm{cm}^{2} \mathrm{sec}$ at the rear face of the shield, and $80 \%$ operation during 20 years, we obtain:

\footnotetext{
(a) In barns $\left(10^{-24} \mathrm{~cm}^{2}\right)$, see Appendix A.

(b) Personal communication from L. L. Carter, Hanford Engineering Development Lab., February 1980.

(c) (displacements per neutron) $\times 10^{-24}$.
} 


$$
\begin{aligned}
& \Phi_{G}(\text { front })=3.73 \times 10^{20} / \mathrm{cm}^{2}, \text { and } \\
& \Phi_{G}(\text { rear })=5.70 \times 10^{18} / \mathrm{cm}^{2}
\end{aligned}
$$

Hanford MWD/AT

Most of the low-temperature irradiation data from the U.S. has been reported in terms of megawatt days of power generation per ton of uranium adjacent to the test facility (MWD/AT). Nightingale ${ }^{(11)}$ reported that one MWD/AT in the water-cooled test hole facilities was equivalent to a fluence of $3.9 \times 10^{17} / \mathrm{cm}^{2}$, thermal neutrons; using this ratio, the thermal-to-fast (E $>0.5 \mathrm{MeV})$ ratio of $10.9^{(\mathrm{a})}$ and the ratio: $\Phi(E>0.183 \mathrm{MeV})^{\prime} \Phi(E>0.498$ Mey $=1.276,(a)$ we calculate that $\Phi(E>0.183)$ is about $4.56 \times$ $10^{16} / \mathrm{cm}^{2}$ per MWD/AT.

deHalas $(13)$ reported that $\Phi(E>1.0 \mathrm{MeV})$ per MWD/AT was measured to be about $3.5 \times 10^{16}$; using this number and the ratio: $\Phi(E>0.183 \mathrm{MeV})^{\prime}$ $\Phi\left(E_{16} 1.05 \mathrm{MeV}\right)=1.481,(a)$ we calculate that $\Phi(E>0.183)$ is about 5.18 $x 10^{16} / \mathrm{cm}^{2}$ per MWD/AT. Using the average of the two values, derived above, and the relationship: $\Phi_{G}=1.18 \times \Phi_{(E>0.183)},{ }^{(3)}$ we conclude that, for the Hanford water-cooled test facilities, $\Phi_{G}=$ MWD/AT $\times 5.75 \times$ $10^{16} / \mathrm{cm}^{2}$.

BEPO nvt

Most of the low-temperature irradiation data from the UK has been reported in terms of BEPO Equivalent Neutron Dose, BEPO nvt, (i.e., the total neutron fluence in the standard test facility in the BEPO Reactor). Hering (14) compared the damage produced (stored energy accumulation rate and the crystallite lattice change rates) per BEPO nvt and the damage produced in the Hanford water-cooled test facilities. Woods, et al., (15) had reported that 1 MWD/AT is equal to $6.46 \times 10^{17} / \mathrm{cm}^{2}$ (total neutron fluence); using this number

(a) Calculated for a similar water-cooled facility in the K-East Reactor at
Hanford. (12) 
and the average value from Hering's comparison: 1 BEPO nvt produces the same damage as 1.08 nvt (total, Hanford), we obtain the result that BEPO nvt/5.98 $x$ $10^{17}=$ MWD/AT. Although other comparisons $(13,16)$ yield numbers between $5.5 \times 10^{17}$ and $6.6 \times 10^{17}$, we shall use the relationship derived above; thus, $\Phi_{G}=0.0962 \times$ BEPO nvt.

In all figures used in this report, the neutron fluences are quoted in terms of $\Phi_{G}$ as per the above relationships. However, for simple comparisons (For example: the relative damage rate as a function of position within the shield composite, or for comparing shield designs with different thickness of steel and graphite.), one can use the relationships,

$$
\begin{aligned}
& \Phi_{G} \quad 0.74 \times \Phi_{(E>15 \mathrm{KeV})} \text { or } \\
& \Phi_{G}=0.80 \times \Phi_{(E>20 \mathrm{KeV})}
\end{aligned}
$$

which are derived in Appendix B.

\section{STORED ENERGY}

The term "stored energy" has been used to denote the increase in internal energy which is associated with the defects produced during irradiation. When these defects are removed (for example, by annealing at a temperature above the irradiation temperature), this excess internal energy is released as sensible heat. Methods for measuring the released stored energy have been reviewed by Bell and Simmons, $(16)$ and by Nightingale. (17)

Total stored energy can be measured by the difference between the heat of combustion of an irradiated and that of an unirradiated sample of graphite. Figure 1 shows the total amount of stored energy accumulated ${ }^{(18)}$ at irradiation temperatures of $25^{\circ} \mathrm{C}, 80-100^{\circ} \mathrm{C}$ and $180^{\circ} \mathrm{C}$ ( (a) However, for the present application, we are primarily concerned with the amount of stored energy released as a function of temperature. Various "linear temperature

(a) The highest fluence shown in Figure 1 is equivalent to less than 2 years exposure at the highest flux position in the shield, but more than 100 years operation at the rear face of the shield. 




FIGURE 1. Total Stored Energy as a Function of Exposure and Irradiation Temperature, Degrees Celsius. 
rise" (LTR), methods have been devised to determine the amount of stored energy release as a function of annealing temperature. Typical release curves $(19)$ are shown in Figure 2 for the samples described in Table 2; only "relative neutron doses" are listed because the samples had been annealed and re-irradiated.

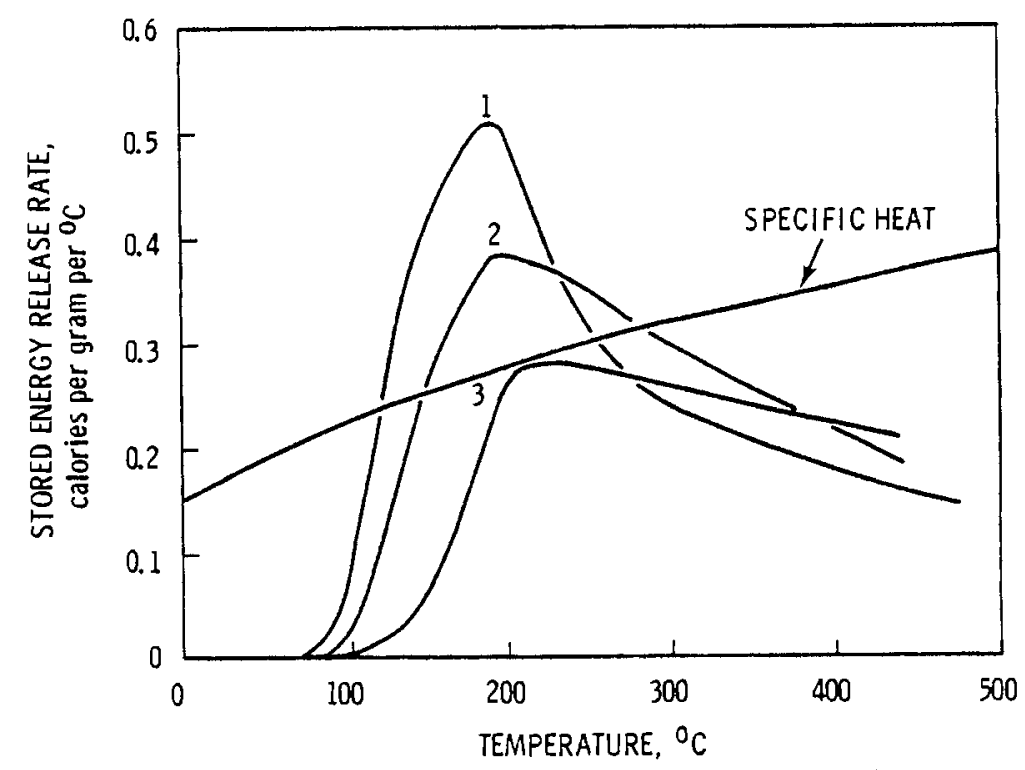

FIGURE 2. Linear-Rise Curves of Stored Energy Release

TABLE 2. Details of Samples in Figure 2

\begin{tabular}{|c|c|c|}
\hline $\begin{array}{l}\text { Number of } \\
\text { Sample }\end{array}$ & $\begin{array}{l}\text { Relative } \\
\text { Neutron } \\
\text { Dose } \\
\end{array}$ & $\begin{array}{l}\text { Estimated Temperature } \\
\text { of Irradiation, }{ }^{\circ} \mathrm{C}\end{array}$ \\
\hline 1 & 0.39 & 30 \\
\hline 2 & 0.81 & 50 \\
\hline 3 & 1.00 & 80 \\
\hline
\end{tabular}

Figure 3 shows a release curve, obtained from a linear rise calorimeter for a graphite sample irradiated at $80^{\circ} \mathrm{C}$ to the equivalent of slightly less than one year of exposure at the front face. One might easily conclude that external heat would be required to increase the sample temperature to Temperature $A$, 


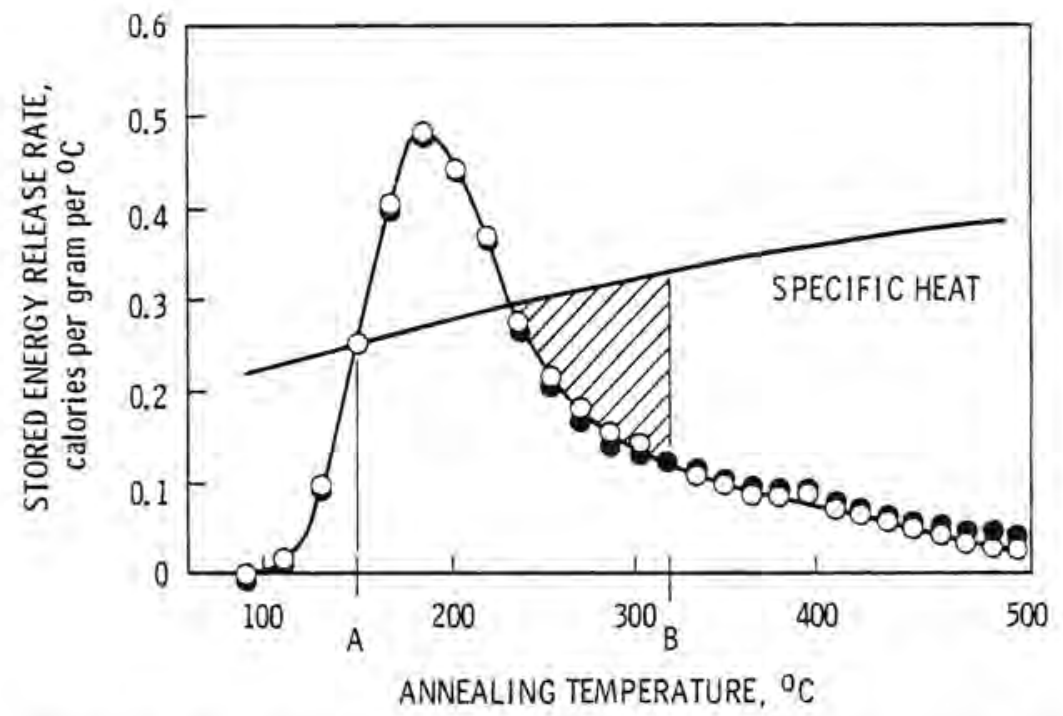

FIGURE 3. Energy Release from Irradiated Graphite. Irradiation: $1.6 \times 10^{19} / \mathrm{cm}^{2}$ at $80^{\circ} \mathrm{C}$,

- specimen 1; o Secimen 2

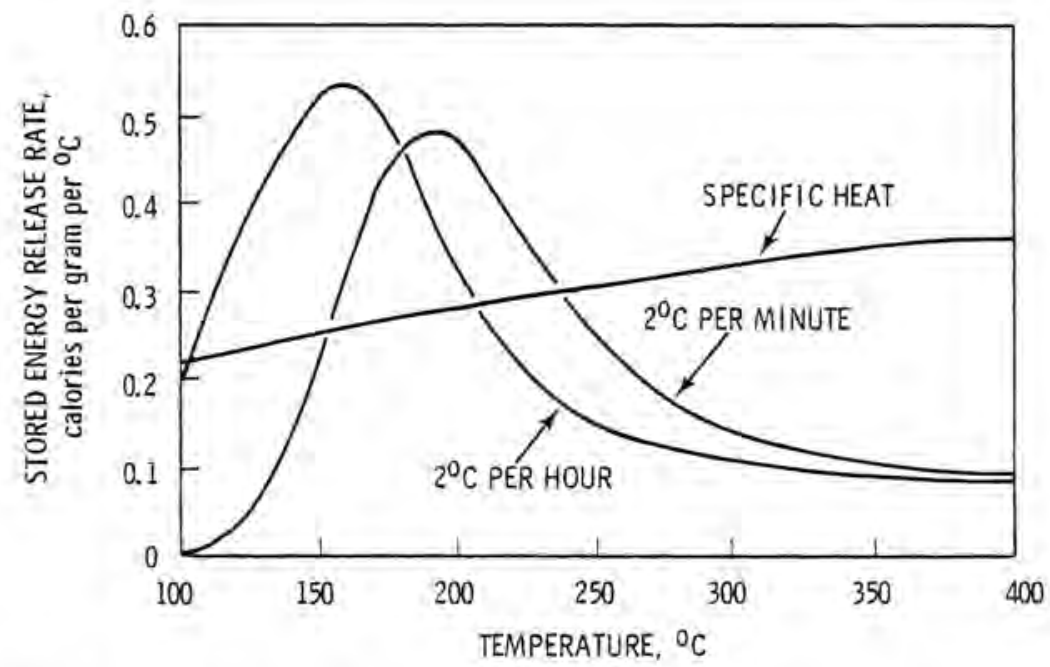

FIGURE 4. Calculated Rate of Release of Energy in a Linear Rise Experiment at $2^{\circ} \mathrm{C}$ per minute and $2^{\circ} \mathrm{C}$ per hour 
and that a spontaneous increase would take place until Temperature $B$ was reached. However, the shape of the release curve is dependent on the rate of temperature rise, as is shown in Figure 4.

It has been shown, by Primak $(20-22)$ and others, ${ }^{(23-26)}$ that the annealing processes are characterized by a broad spectrum of activation energies; this result implies that the amount of stored energy released will depend on irradiation duration and the time-temperature history during storage, $(21,27)$ as well as the fluence and irradiation temperature. This is an area where much additional experimental and analytical work needs to be done. However, the uncertainties introduced are, for our present purposes, probably not more significant than the uncertanties introduced by lack of solid information on the irradiation conditions and accuracy of the measurement techniques.

Where the stored energy release exceeds the specific heat, as in Figure 3 , adiabatic calorimetry can provide much more useful information than can linearrise calorimetry. The technique used for adiabatic calorimetry is to initiate a stored energy release in the sample and then to follow the time-temperature history without allowing either a heat-gain-from or a heat-loss-to, the external surroundings. Two such adiabatic release curves ${ }^{(28)}$ are shown in Figure 5 . The "starting temperature (the temperature at which a self-sustained $r$ ise in temperature is initiated) is really a range of temperatures; at the lower "starting temperatures" the rate of stored energy release is quite slow. The rate-of-release of stored energy changes by about an order of magnitude for each $20^{\circ} \mathrm{C}$ change in "starting temperature", ${ }^{(19)}$ so it becomes progressively more difficult to obtain adiabatic conditions as the "starting temperature" is reduced; this effect is illustrated in Figure 6 .

Nevertheless, it is useful to define the "starting temperature" as the temperature at which the adiabatic temperature rise reaches some defined rate. Figure 7 shows a correlation between "starting temperature" and irradiation temperature, where the starting temperature is defined as the temperature at which the rate-of-rise is $12^{\circ} \mathrm{C} / \mathrm{min}$. As can be seen from Figure 7 , the starting temperature is generally 30 to $50^{\circ} \mathrm{C}$ above the irradiation temperature. (28) 


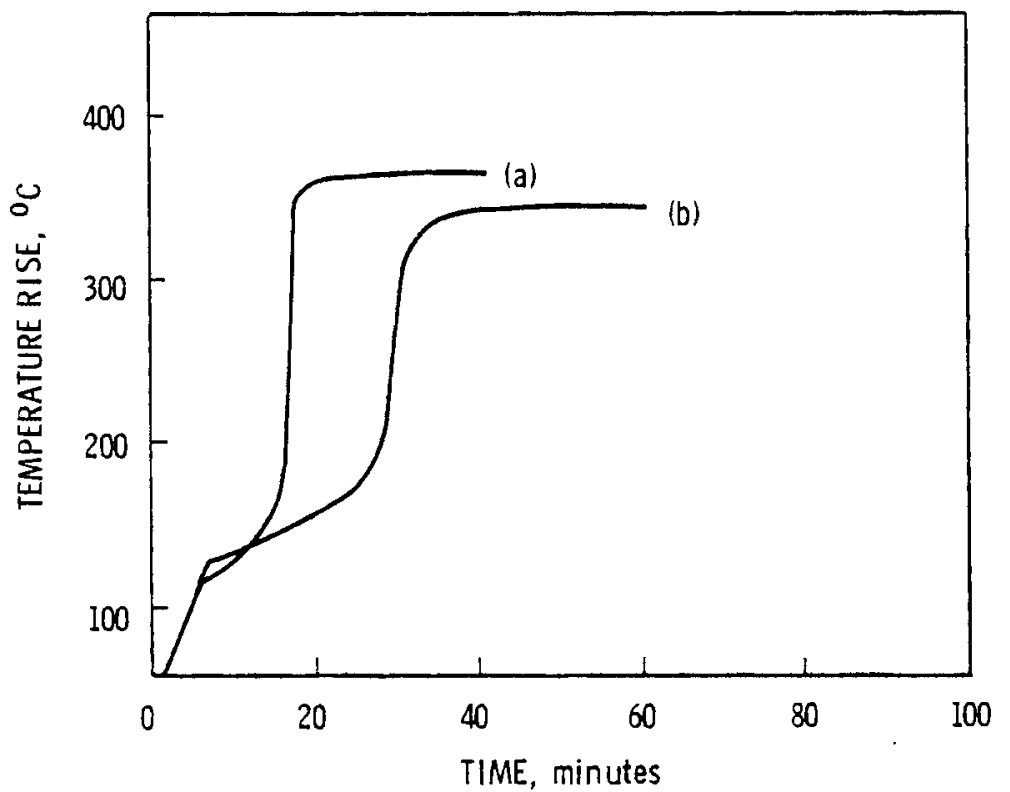

FIGURE 5. Adiabatic Rise Curves. Irradiation: (a) $35^{\circ} \mathrm{C}$, $1.8 \times 10^{19} / \mathrm{cm}^{2}$, (b) $70^{\circ} \mathrm{C}, 3.1 \times 1019 / \mathrm{cm}^{2}$

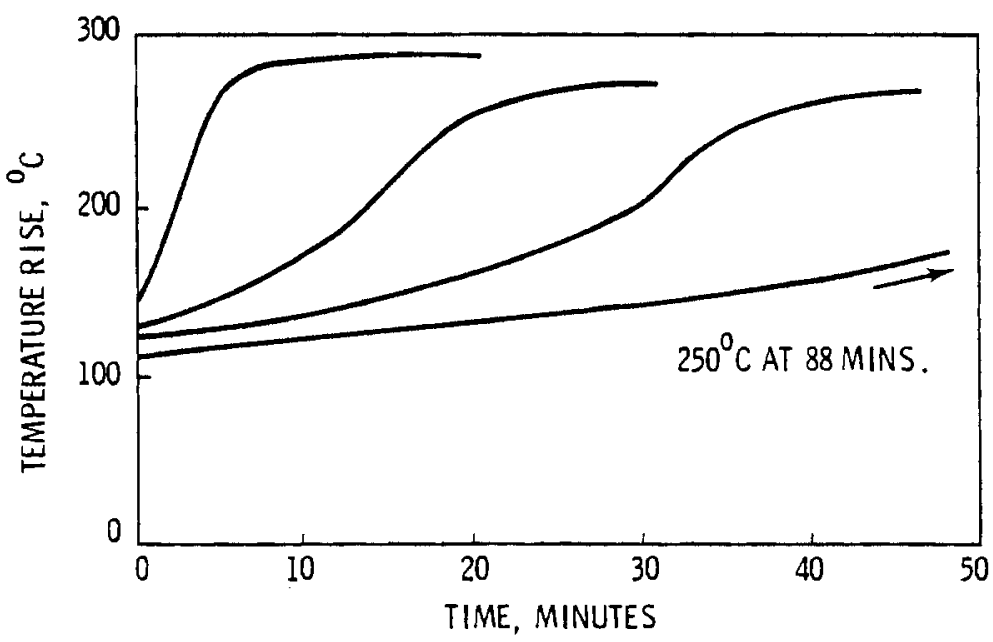

FIGURE 6. The Effect of Starting Temperature on Adiabatic Energy Release. Irradiation: $25^{\circ} \mathrm{C}, 1.3 \times 10^{19}$ total dose, $0.6 \times 10^{19}$ since last anneal. 


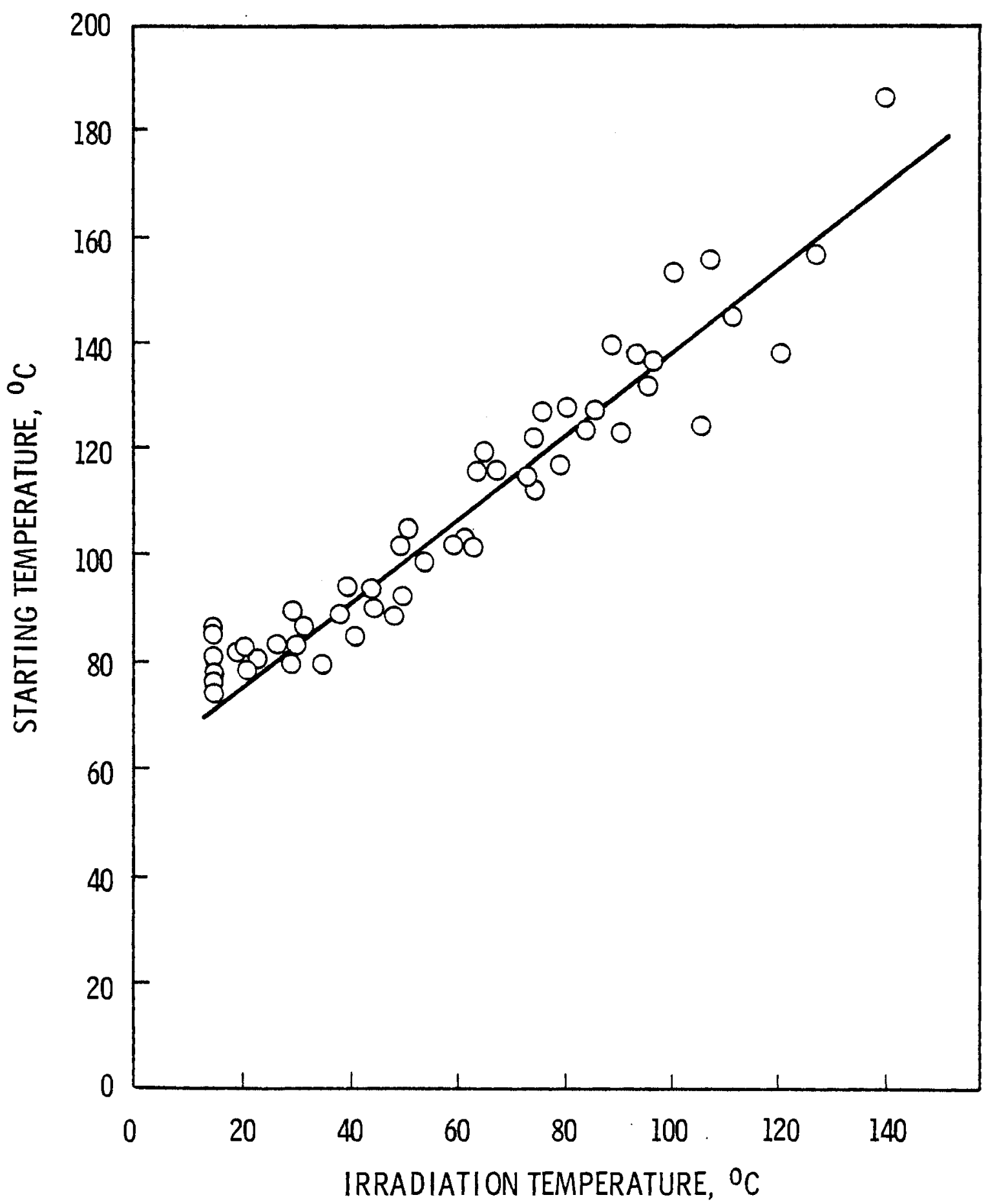

FIGURE 7. Effect of Irradiation Temperature on the Starting Temperature to Give Standard Adiabatic Release Rate 
Figure 8 shows the amount of stored energy released adiabatically, (18) as a function of irradiation temperature and neutron fluence. (a) The amount of available data is very small; but, it can be seen that the amount releasable from a graphite irradiated at $80^{\circ} \mathrm{C}$, to the equivalent of 2 years at the position of maximum fluence in the test cell shield, should not exceed about 65 calories per gram. Figure 9 shows the heat capacity of graphite ${ }^{(29)}$ as a function of temperature. Assuming a starting temperature of $80+40^{\circ} \mathrm{C}=120^{\circ} \mathrm{C}$ and 65 calories per gram released, the maximum temperature which the graphite could reach (under adiabatic conditions) would be $345^{\circ} \mathrm{C}$. Under actual conditions the release would not occur adiabatically, the full $65 \mathrm{cal} / \mathrm{gm}$ would not be released, and the maximum temperature would be less than $345^{\circ} \mathrm{C}$.

Moreover, it can be seen that the amount of stored energy which is adiabatically releaseable is rapidly approaching a saturation value; the total stored energy continues to increase, but not the amount released adiabatically.

Only a very small amount of information on annealing of stored energy is available at exposures greater than shown in Figure 8 . Neubert and Lees (23) reported that $40 \mathrm{cal} / \mathrm{gm}$ was released below $250^{\circ} \mathrm{C}$ (during a $9-10^{\circ} \mathrm{C} / \mathrm{min}$. LTR) from a sample irradiated to $5.8 \times 10^{19} / \mathrm{cm}^{2}$ at $55^{\circ} \mathrm{C}$ in a Hanford CTH. Powell, et. al., reported ${ }^{(30)}$ about the same stored energy was released below $300^{\circ} \mathrm{C}$ after one-half of that exposure at $55^{\circ} \mathrm{C}$ in the Oak Ridge Reactor. Morgan (b) annealed graphite samples, which had been irradiated $(26)$ in the Hanford CTH to $2.85 \times$ $10^{20} / \mathrm{cm}^{2}$ and $6.05 \times 10^{20} / \mathrm{cm}^{2}$ (equivalent to about 15 and 32 years, respectively at the highest fluence position in the FMIT test cell shield). These anneals ( $51 / 2 \mathrm{hr}$ at $350^{\circ} \mathrm{C}$ ) reduced the total stored energy by 72.0 and $86.5 \mathrm{cal} / \mathrm{gm}$ respectively. Although precise irradiation temperatures are not known, they were certainly less than $80^{\circ} \mathrm{C}$. Thus, the evidence indicates that the maximum stored energy released adiabatically from graphite irradiated at $80^{\circ} \mathrm{C}$

(a) Note: Although the curves are drawn as continuous from zero fluence, one should not interpret this as an indication that an adiabatic release could occur in any reasonable time-frame at the lower fluences. At the lower levels of releasable stored energy, an adiabatic release might require months or years (rather than the minutes shown in Figure 4) and, consider ing the time-scale involved, the release would certainly not be adiabatic.

(b) Unpublished data, W. C. Morgan, Hanford Atomic Products Operation, May and August 1962. 


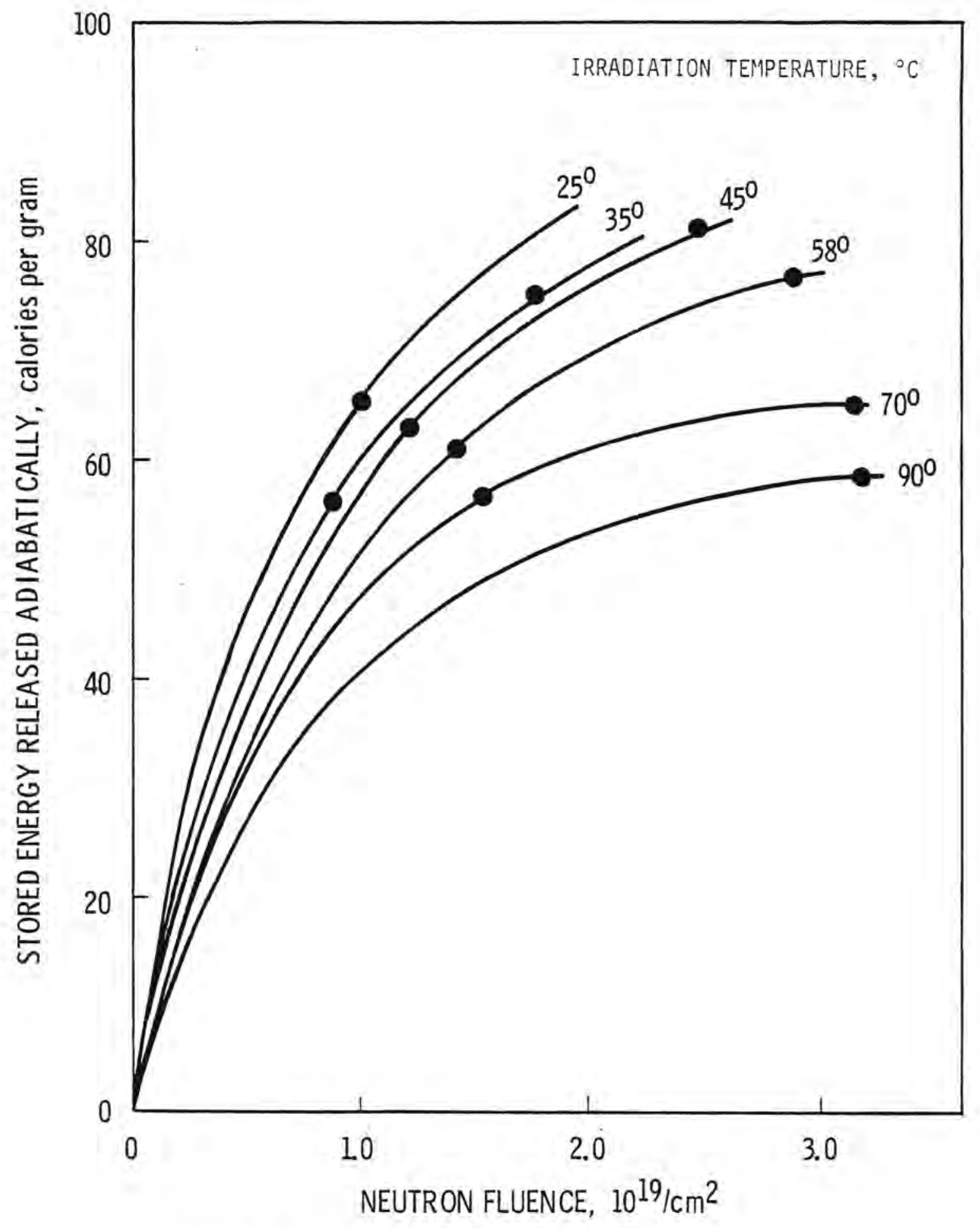

FIGURE 8. Adiabatically Released Stored Energy 


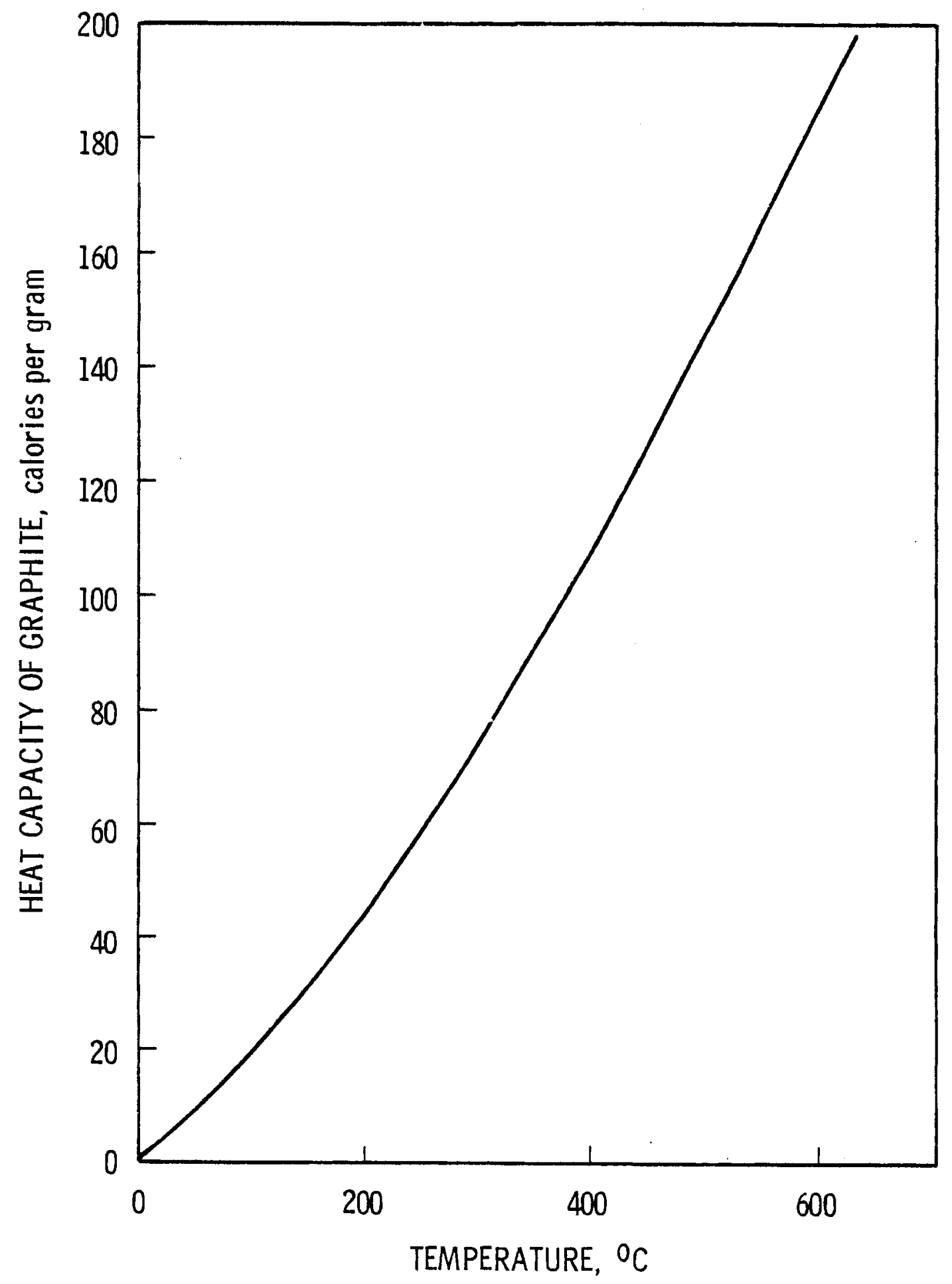

FIGURE 9. Heat Capacity of Graphite 
will not exceed $80 \mathrm{cal} / \mathrm{gm}$; an adiabatic release of this magnitude would produce a temperature of about $390^{\circ} \mathrm{C}$.

The above conclusion is also compatible with observations reported on annealing of nuclear reactor moderators; $(28,30)$ maximum temperatures on the order of $300^{\circ} \mathrm{C}$ have been observed during a kinetic release of stored energy.

During a typical stored energy annealing operation at $\operatorname{BEPO}(19,28)$ the graphite is slowly heated by slowly increasing the temperature of the flowing air; graphite temperatures first lag behind the air temperatures, then slowly increase and, finally, increase rapidly (about $10^{\circ} \mathrm{C} / \mathrm{min}$ ) at some position within the moderator. Following this rapid rise, the release phenomenon proceeds to spread like a thermal wave, moving with a velocity of about $2 \mathrm{~cm} / \mathrm{min}$ as predicted by Foreman. (31)

If the heating of the air was discontinued, or the air temperature was reduced, appreciable annealing could still occur without initiating the rapid temperature rise and the resultant thermal wave (see Figure 6).

Figure 10 illustrates $(19)$ the effect of isothermal annealing, below the critical cemperature, on the spontaneous temperature rise. The four runs are on pieces of a sample irradiated at about $40^{\circ} \mathrm{C}$ in Windscale. All LTR runs were made at $2^{\circ} \mathrm{C} / \mathrm{min}$; samples $\mathrm{B}, \mathrm{C} \& \mathrm{D}$ were first heated to $110^{\circ} \mathrm{C}$ at $2^{\circ} \mathrm{C} / \mathrm{hr}$ (see Figure 4), prior to the LTR runs; samples $C$ and $D$ were then held at $110^{\circ} \mathrm{C}$ for 48 hours and 240 hours, respectively, before the LTR run.

\section{OTHER EFFECTS}

- Commercial (non-nuclear) grade graphites may contain a few hundred parts per million (each) of such impurities as iron, calcium, sulfur, and silicon; however, except for boron ${ }^{(32)}$, none of the impurities are known to affect the changes in physical properties during irradiation. Low boron content is desirable for commercial electrode graphites, and can be specified on the purchase specifications. 


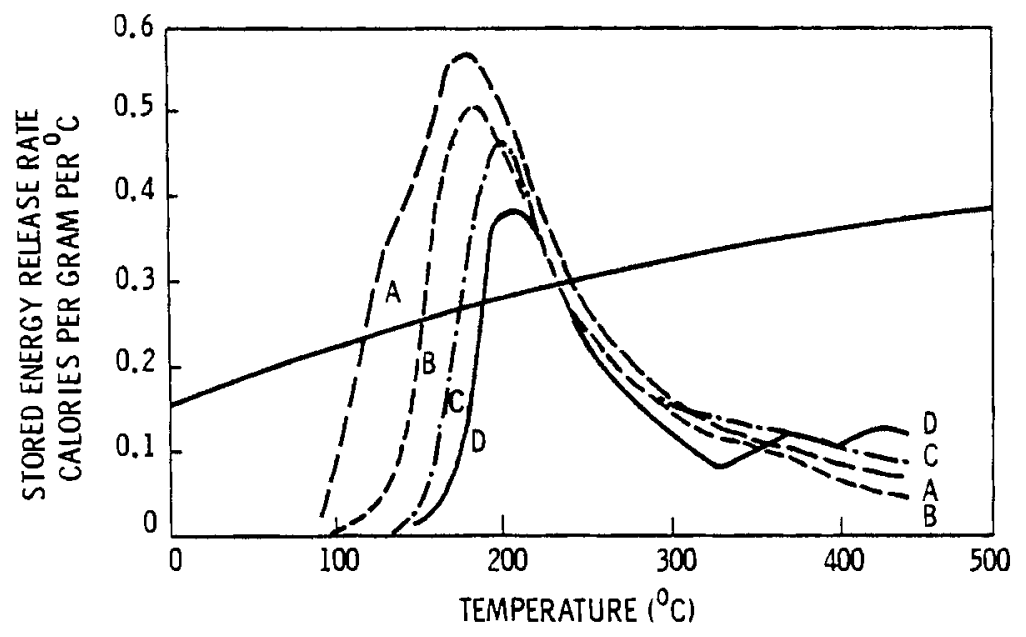

FIGURE 10. Effect of Pretreatment at $110^{\circ} \mathrm{C}$ on Linear-Rise Curves

- Dimensional changes are highly dependent ${ }^{(33-35)}$ on the raw materials and processing conditions used to manufacture the graphite, as well as on the irradiation temperature. Manufacturing processes and sources of raw material are generally considered propritary by the graphite manufacturers, so it is advisable to work with the manufacturer in selecting material for a particular application.

In general, it can be said that small crystallite size, low thermal expansion and minimum graphitization temperatures are desirable properties if one is seeking minimum dimensional changes at low temperatures. TSGBF ${ }^{(a)}$ (TexasLockport coke, Standard coal-tar-pitch binder, Gas Bake graphitization process, "E" purification process), which was used in the $K$ Reactors, meets these criteria and is the most dimensionally stable production-grade nuclear graphite which has been irradiated in the Hanford CTH. After a CTH exposure equivalent to the maximum in the FMIT shield, the TSGBF samples had contracted (36)

(a) TSGBF was a "limited production" grade, produced using coke from a single source during a brief span of time; coke from a single source varies with time as the feed-stock changes. Even the feed-stock derived from a single oil well changes with time; thus, a "TSGBF", produced today, would not be identical to the TSGBF which was produced and tested more than 25 years ago. 
about $0.3 \%$ in the direction parallel to, and expanded about $1.8 \%$ in the direction transverse to, the axis of extrusion of the bar. An irradiation temperature of $80^{\circ} \mathrm{C}$ would decrease the transverse expansion, $(25,37)$ but could increase the parallel contraction.

Simmons has postulated (37) that a graphite with a mean thermal expansion coefficient of $0.75 \times 10^{-6} /{ }^{\circ} \mathrm{C}$, measured over the temperature range $-130^{\circ} \mathrm{C}$ to $-20^{\circ} \mathrm{C}$, should be dimensionally stable when irradiated at $80^{\circ} \mathrm{C}$; however, although there is a general agreement between the theory and experimental data, there are significant discrepancies $(37,38)$ which preclude its literal use, especialy over a wide exposure range, such as for the FMIT test cell shield.

- Reductions in thermal conductivity by a factor of 10 to $20(15,33-35)$ may be expected, depending on the grade of graphite. This change will be beneficial in that it will increase the interior temperatures of the graphite slabs and, thus, reduce the stored energy.

- Carbon-14 will be produced by the ${ }^{13} \mathrm{C}(n, y){ }^{14} \mathrm{C}$ activation reaction, with the naturally occuring ${ }^{13} \mathrm{C}$ being augmented by the ${ }^{12} \mathrm{C}(n, y){ }^{13} \mathrm{C}$ reaction; however, the ${ }^{14} \mathrm{~N}(n, p){ }^{14} \mathrm{C}$ activation reaction may be of more importance, expecially as this ${ }^{14} \mathrm{C}$ will be produced in the circulating coolant.

\section{CONCLUSIONS AND RECOMMENDATIONS}

1. There do not appear to be any major problems associated with use of graphite in the composite shield structure.

2. The grade of graphite should be selected, primarily, on the basis of cost and estimated dimensional stability.

3. The purchasing agent should work with the manufacturer's "productoriented" staff in selecting the graphite "grade", or the materials and process used to produce the final product.

4. Serious consideration should be given to periodic (yearly) low temperature annealing of the stored energy and dimensional changes. 
5. After 20 years operation without annealing, an adiabatic release of stored energy would increase the temperature of the graphite in the front shield panel to about $400^{\circ} \mathrm{C}$ and the temperature of the rear panel to about $250^{\circ} \mathrm{C}$. Heat transfer to the steel and coolant during the release would decrease a) the graphite temperature as a function of time, b) the rate of stored energy release, c) the amount of stored energy released, and d) the maximum temperature which could be attained at the end of the release. 
APPENDIX A

DAMAGE CROSS SECTIONS

The energy ranges of the group structure, reported by Carter, (b) are rather broad for radiation damage calculations; however, they are adaquate, considering the present uncertainties in shield design and the antiquity of the radiation damage data. The group-averaged cross-sections used to calculate the Relative Damage (see Table 1) were obtained in the following way:

1. Zijp ${ }^{(9)}$ used the Thompson and Wright form of the damage function, (5) with the total scattering cross-section for carbon from the Winfrith (Aldermaston) Nuclear Data Library, ${ }^{(39)}$ to calculate the group-averaged damage cross-sections shown in Table 3. The PEGGI (9) form of the fission neutron spectrum was used to average $(a)$ the cross-sections for the two groups above $0.1 \mathrm{MeV}$ :

$$
\begin{aligned}
& \int_{0}^{2.25} \sigma(U) \phi(U) d U / \int_{0}^{2.25} \phi(U) d U=726 \text { barns } \\
& \int_{2.25}^{4.50} \sigma(U) \phi(U) d U / \int_{2.25}^{4.50} \phi(U) d U=732 \text { barns }
\end{aligned}
$$

Where $U$ is lethargy,

$U=\operatorname{Ln} E_{0} / E$,

with $E_{0}=10 \mathrm{MeV}$.

At the lower energies, it is not possible to average the cross-sections in this manner; therefore, a smoothed decrease in cross-section was assumed for the regions below Lethargy $4.50(E=111.1 \mathrm{KeV})$. Table 4 lists the smoothed cross-sections; a simple average was then obtained (i.e., $\phi(U)=$ a constant) for each of the two other groups above $1.0 \mathrm{KeV}$ :

(a) Although the averaging process is denoted here as an integral, in actuality the averages were obtained by summation of the group-averaged quantities (b) Personal communication from L. L. Carter, Hanford Engineering Development
Lab., February 1980 . 
TABLE 3. $235 U$ Fission Spectrum-Averaged Cross Sections

\begin{tabular}{|c|c|c|c|c|c|c|}
\hline Group & Letharg & y Range & Lower E & ergy & $\begin{array}{c}\sum_{d(a)} \\
\text { (barns) }\end{array}$ & $\begin{array}{l}\text { Relative } \\
\text { Flux(b) }\end{array}$ \\
\hline 1 & 0 & -0.25 & 7.79 & $\mathrm{MeV}$ & 610 & 0.0248 \\
\hline 2 & 0.25 & -0.50 & 6.07 & $\mathrm{MeV}$ & 632 & 0.0681 \\
\hline 3 & $0.50-$ & 0.75 & 4.72 & $\mathrm{MeV}$ & 548 & 0.1580 \\
\hline 4 & $0.75-$ & 1.00 & 3.68 & $\mathrm{MeV}$ & 827 & 0.2753 \\
\hline 5 & $1.00-$ & 1.25 & 2.86 & $\mathrm{MeV}$ & 882 & 0.3855 \\
\hline 6 & $1.25-$ & 1.50 & 2.26 & $\mathrm{MeV}$ & 669 & 0.4533 \\
\hline 7 & $1.50-$ & $\quad 1.75$ & 1.74 & $\mathrm{MeV}$ & 679 & 0.4761 \\
\hline 8 & $1.75-$ & 2.00 & 1.35 & $\mathrm{MeV}$ & 701 & 0.4502 \\
\hline 9 & $2.00-$ & 2.25 & 1.05 & $\mathrm{MeV}$ & 747 & 0.3949 \\
\hline 10 & $2.25-$ & - 2.50 & 0.821 & $\mathrm{MeV}$ & 777 & 0.3275 \\
\hline 11 & $2.50-$ & 2.75 & 0.639 & $\mathrm{MeV}$ & 792 & 0.2600 \\
\hline 12 & $2.75-$ & 3.00 & 0.498 & $\mathrm{MeV}$ & 772 & 0.1996 \\
\hline 13 & $3.00-$ & 3.25 & 0.387 & $\mathrm{MeV}$ & 736 & 0.1754 \\
\hline 14 & $3.25-$ & 3.50 & 0.302 & $\mathrm{MeV}$ & 694 & 0.1098 \\
\hline 15 & $3.50-$ & 3.75 & 0.235 & $\mathrm{MeV}$ & 639 & 0.0794 \\
\hline 16 & $3.75-$ & 4.00 & 0.183 & $\mathrm{MeV}$ & 570 & 0.0569 \\
\hline 17 & $4.00-$ & - 4.25 & 0.143 & $\mathrm{MeV}$ & 490 & 0.0402 \\
\hline 18 & $4.25-$ & 4.50 & 0.111 & $\mathrm{MeV}$ & 410 & 0.0284 \\
\hline 19 & $4.50-$ & 4.75 & 86.5 & $\mathrm{keV}$ & 338 & 0.0199 \\
\hline 20 & $4.75-$ & $\quad 5.00$ & 67.4 & $\mathrm{keV}$ & 277 & 0.0138 \\
\hline 21 & $5.00-$ & 7.00 & 9.12 & keV & 105 & 0.0037 \\
\hline 22 & $7.00-$ & 9.00 & 1.23 & $\mathrm{keV}$ & & 0.00019 \\
\hline 23 & $9.00-$ & -11.00 & 0.167 & keV & & 0.000013 \\
\hline 24 & $11.00-$ & -13.00 & 22.6 & $\mathrm{eV}$ & & 0 \\
\hline 25 & $13.00-$ & -15.00 & 3.06 & $\mathrm{eV}$ & & 0 \\
\hline 26 & $15.00-$ & 16.5884 & 0.625 & $\mathrm{eV}$ & & 0 \\
\hline 27 & $>16.5884$ & & (thern & & & \\
\hline
\end{tabular}

(a) See References 3 and 9.

(b) Flux per unit lethargy, $\phi(U)$, in this group (Reference 9). $\begin{aligned} \int_{0}^{5.0} \phi(U) & =1.000 \\ \int_{0}^{\infty} \phi(U) & =1.0079\end{aligned}$ 


$$
\begin{aligned}
& \int_{4.50}^{6.25} \sigma(U) \phi(U) d U / \int_{4.50}^{6.25} \phi(U) d U=207 \text { barns } \\
& \int_{6.25}^{9.25} \sigma(U) \phi(U) d U / \int_{6.25}^{9.25} \phi(U) d U=74 \text { barns }
\end{aligned}
$$

TABLE 4. Extrapolated Cross Sections

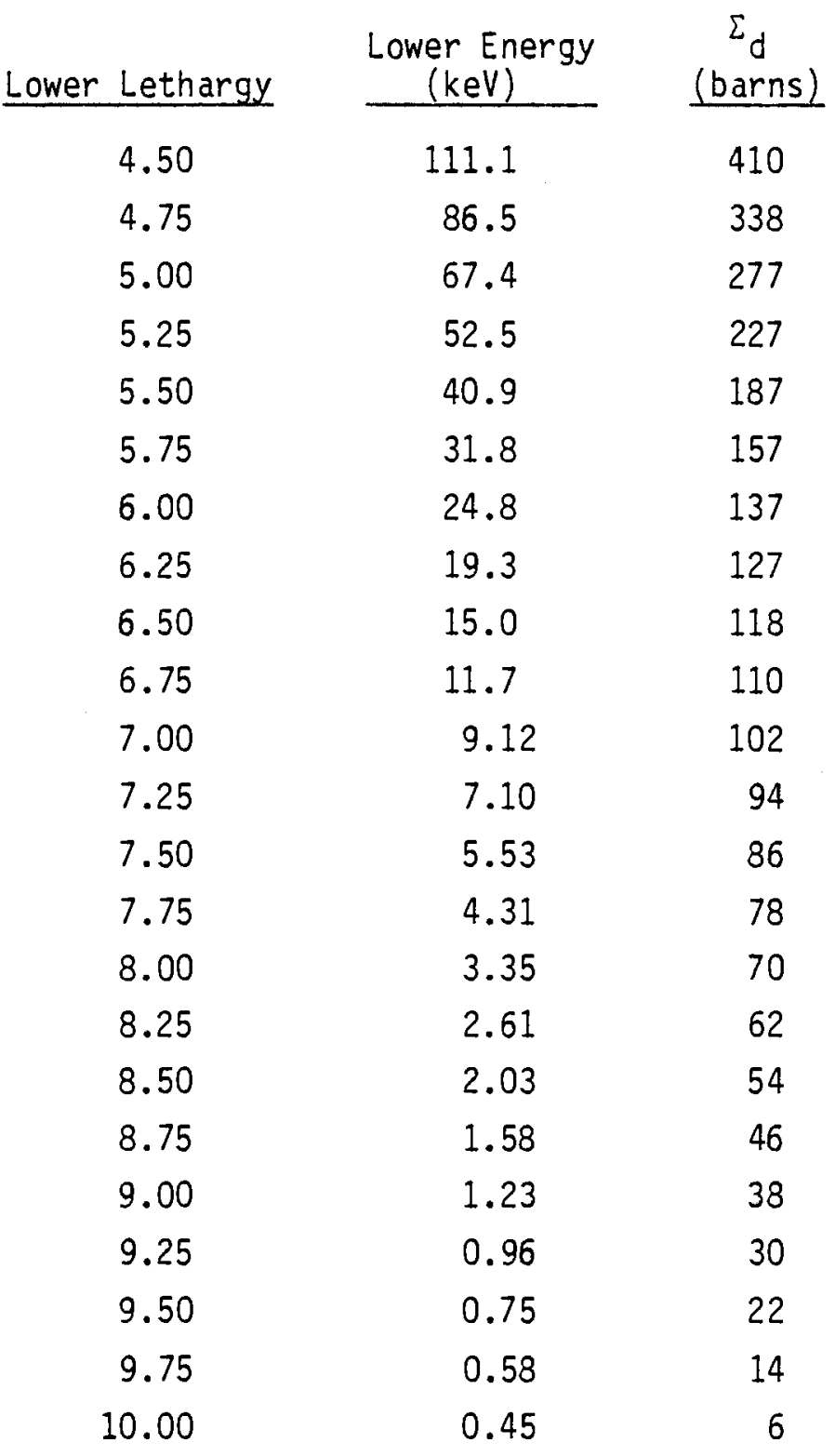



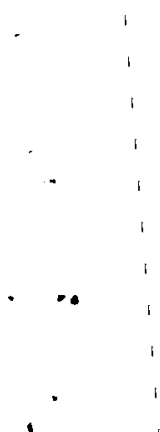

, 
APPENDIX B

\section{A USEFUL EXPOSURE UNIT}

In 1963, Dahl and Yosikawa ${ }^{(40)}$ showed that a unique energy, $E_{1}$, could be identified such that the ratio:

$$
\bar{\Sigma}_{d\left(E>E_{1}\right)}=\frac{\int_{0}^{\infty} \bar{\Sigma}_{d}(E) \phi(E) d E}{\int_{E_{1}}^{\infty} \phi(E) d E}
$$

remained a constant for a wide variety of neutron spectra. Thus, Equation 1 can be written in the form:

$$
\Phi_{G}=\frac{\bar{\Sigma}_{d\left(E>E_{1}\right)} \int_{t_{1}}^{t_{2}} \int_{E_{1}}^{\infty} \phi(E, t) d E d t}{\bar{\Sigma}_{f}}
$$

However, $\Phi\left(E>E_{1}\right) \equiv \int_{t_{1}}^{t_{2}} \int_{E_{1}}^{\infty} \phi(E, t) d E d t$, and

Equation 1 can be rewritten as:

$$
\Phi_{G}=\frac{\bar{\Sigma}_{d}\left(E>E_{1}\right)}{\bar{\Sigma}_{f}} \Phi\left(E>E_{1}\right)
$$

where the ratio $\quad \bar{\Sigma}_{d}\left(E>E_{1}\right) / \bar{\varepsilon}_{f} \quad$ is approximately constant over a wide range of neutron spectra. Moreover, they reported that the result $E_{1}=$ $0.065 \mathrm{MeV}$ was obtained (for various fission reactor spectra), even when quite different models were used for $\Sigma_{d}(E)$. This result has been confirmed by several other investigators, $(41-43)$ and provides a useful tool for estimating the change in damage production per neutron as the neutron flux spectrum is altered (for example, by deeper penetration into the shield). 
Table 5 lists the ratio of the damage fluence, $\Phi_{G}$, to the total fluence of neutrons with energy greater than $E_{1},{ }^{\Phi}\left(E>E_{1}\right)$, for the neutron flux spectrum at the front and rear faces of the shield composite. The ratios are plotted in Figure 11, and it can be seen that:

$$
\Phi_{G} \simeq 0.74 \times \Phi(E>15 \mathrm{KeV}) \text { or } 0.80 \times \Phi(E>20 \mathrm{KeV})
$$

For simple projections of the damage production in the graphite laminations within different steel/graphite composites these relationships should be reasonably accurate.

TABLE 5 . Calculation of Fluence Ratios

\begin{tabular}{|c|c|c|c|c|}
\hline \multirow[b]{2}{*}{$\begin{array}{c}\text { Energy, } \\
E_{1}\end{array}$} & \multicolumn{2}{|c|}{ Front Face } & \multicolumn{2}{|c|}{ Rear Face } \\
\hline & $\phi\left(E>E_{1}\right)$ & $\frac{\Phi_{G}}{\Phi\left(E>E_{1}\right)}$ & $\phi\left(E>E_{1}\right)$ & $\frac{\Phi_{G}}{\phi\left(E>E_{1}\right)}$ \\
\hline $1.0 \mathrm{MeV}$ & 0.028 & 14.29 & 0.030 & 4.67 \\
\hline $0.1 \mathrm{MeV}$ & 0.320 & 1.25 & 0.094 & 1.49 \\
\hline $20 \mathrm{keV}$ & 0.505 & 0.79 & 0.170 & 0.82 \\
\hline 1.0 & 0.719 & 0.56 & 0.389 & 0.36 \\
\hline
\end{tabular}




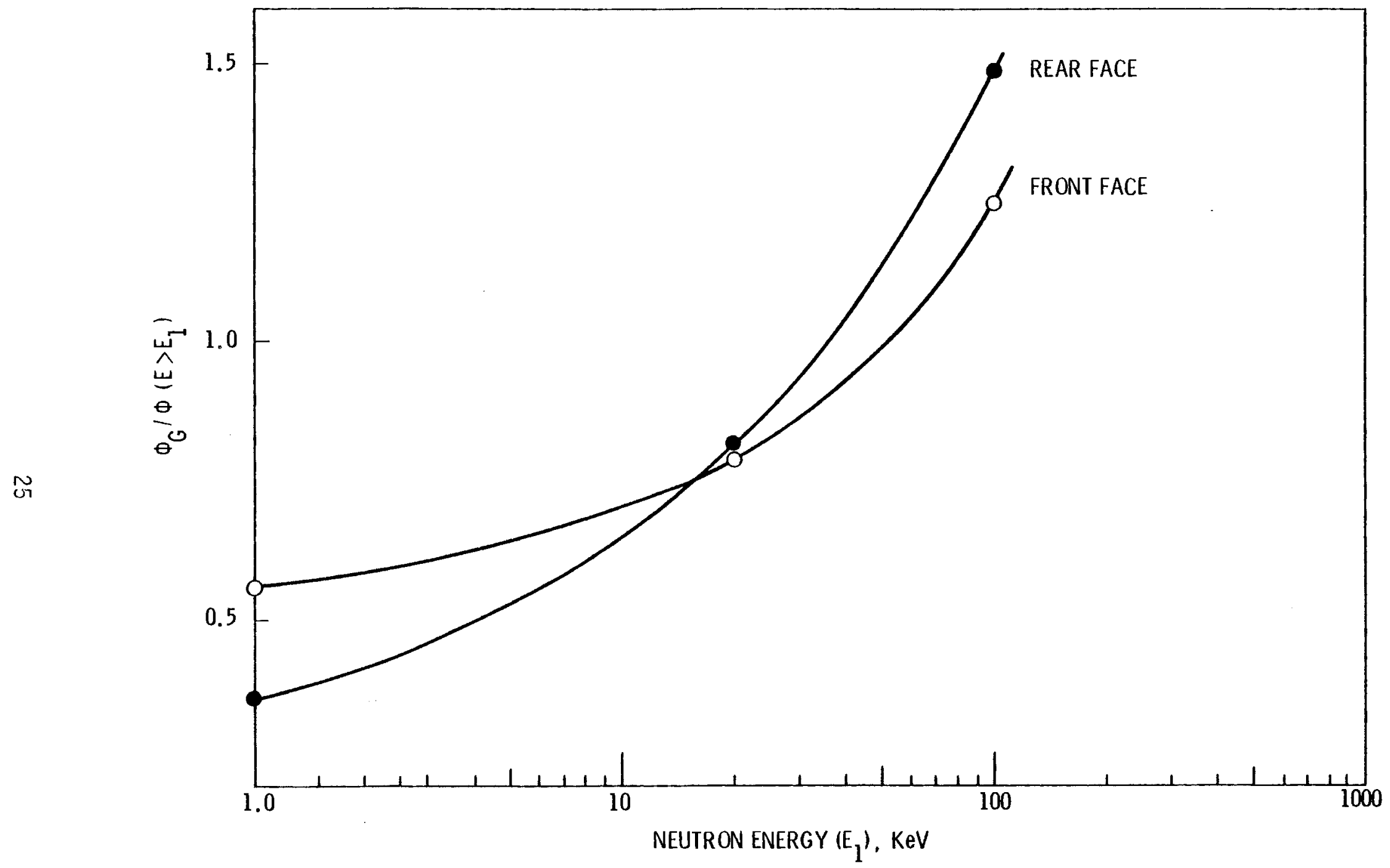

FIGURE 11. Ratio of Damage Fluence to Fluence of Neutrons with Energy Greater Than $E_{1}$ 



\section{REFERENCES}

1. "Test Cell Cooling Design Basis Report," The Ralph M. Parsons Company, Pasadena, Ca, October 1979.

2. "Special Issue: IAEA Specialists' Meeting on Radiation Damage Units in Graphite and Ferritic and Austenitic Steels," Nucle. Eng. Design, 33(1), (1975).

3. Morgan, W. C., "Neutron Fluence and Atomic Displacement Rates for Graphite Irradiations", Nucl. Tech., 21, 50 (1974).

4. "Recommended Practice for Reporting Dosimetry Results on Nuclear Graphite," Annual Book of ASTM Standards, Part 45.

5. Thompson, M. W. and S. B. Wright, "A New Damage Function for Predicting the Effect of Reactor Irradiation of Graphite in Different Neutron Spectra," J. Nucl. Mater., 16, 146 (1965).

6. Morgan, $W C$. , "Atomic Displacement Cross Sections for Carbon from ENDF/B-II I Data", J. Nucl. Mater., 51, 209 (1974).

7. Gray, W. J. and W. C. Morgan, "Damage Function for Carbon at Neutron Energies up to $15 \mathrm{MeV}$ ", J. Nucl. Mater., 86, 237 (1979).

8. Valette, L. J., "Correlation of Fast-Neutron Damage for HTGR Core Material," Radiation Damage in Reactor Materials, Vol. 2, STI/PU3/230, International Atomic Energy Agency, Vienna, 1969, pp. 97-113.

9. Zijp, Willem L. and H. Ch. Rieffe, "Comparison of the Annual Available Damage Fluences in DFR, EBR-2 and HFR", RCN-161, Reactor Centrum Neder land, The Hague, Nether lands, 1972.

10. Genthon, J. P.,"Recommendations sur les Measures des Irradiations Recues par les Materiaux de Structure de Piles," EUR-4867 (CONF 2104), Joint Nuclear Research Centre, Ispra, 1972.

11. Nightingale, R. E., "Irradiation Annealing in Graphite I. An Experimenta] Study", US/UK Graphite Conference, TID-7567 (Pt. 1), March 1959, pp. 21-32.

12. Serpan, C. Z., Jr. and B. H. Menke, "Nuclear Reactor Neutron Energy Spectra", ASTM, DS-52, Apri1 1974.

13. deHalas, D. R., "Theory of Radiation Effects in Graphite", Nuclear Graphite, R. E. Nightingale (editor), Academic Press, New York, 1962, pp. 195-238.

14. Hering, H., Discussion of a paper by J. H. W. Simmons, Industrial Carbon and Graphite, Soc. Chem. Ind., London, 1958, pp. 517-518. 
15. Woods, W. K., L. P. Bupp and J. F. Fletcher. "Irradiation Damage to Artificial Graphite", Proceedings of the International Conference on the Peaceful Uses of Atomic Energy, Vol. 7, U.N., New York, 1956, pp. $455-471$.

16. Bell, J. C. and J. H. W. Simmons, "Experimental Methods for Determining Stored Energy", US/UK Graphite Conference, TID-7565 (pt. 1), March 1959, pp. 82-101.

17. Nightingale, R. E., "Stored Energy", Nuclear Graphite, R. E. Nightingale (editor), Academic Pres, New York, 1962, pp. 325-353.

18. Simmons, J. H. W., "Irradiation Damage in Graphite", US/UK Graphite Conference, TID-7565 (Pt. 1), March 1959, pp. 88-101.

19. Cottre11, A. H., J. C. Be11, G. B. Greenough, W. M. Lomer and J. H. W. Simmons, "Theory of Annealing Kinetics Applied to the Release of Stored Energy from Irradiated Graphite in Air-Cooled Reactors", Proceedings of the Second United Nations International Conference on the Peaceful Uses of Atomic Energy, Vol. 7, U.N. Geneva, 1958, pp. 315-327.

20. Primak, W., Phys. Rev, 100, 1677 (1955).

21. Primak, W. L., H. Fuchs, and P. P. Day, "Radiation Damage in Diamond and Silicon Carbide", Phys. Rev., 103, 1184 (1956).

22. Primak, W., "Fast-Neutron Damaging in Nuclear Reactors: Its Kinetics and the Carbon Atom Displacement Rate", Phys. Rev., 103, 1681 (1956).

23. Newbert, T. J. and R. B. Lees, "Stored Energy in Neutron-Bombarded Graphite", Nucl. Sci. Eng., 2, 748 (1957).

24. Nightingale, R. $\varepsilon$. and W. A. Synder, "Distribution of Radiation Damage in Graphite", Proceedings of the Third Carbon Conference, Pergamon Press, London, 1959, pp. 579-584.

25. Nightingale, R. E. and J. F. Fletcher, "Radiation Damage to Graphite from $30^{\circ}$ to $185^{\circ} \mathrm{C} "$, Proceedings of the French-American Conference on Graphite Reactors, BNL-489, November 1957, pp. 32-41.

26. Davidson, J. M., "Stored Energy in Irradiated Graphite", US/UK Graphite Conference, TID-7565 (Pt. 1), March 1959, pp. 11-20.

27. Primak, W., "Fast Neutron Damaging in Nuclear Reactors. III. The Radiation Damage Dosage", Nucl. Sci. Eng., 2, 320 (1957).

28. Dickson, J. L., G. H. Kinchin, R. F. Jackson, W. M. Lomer, and J. H. W. Simmons, "BEPO Wigner Energy Release", Proceedings of the Second United Nations International Conference on the Peaceful Uses of Atomic Energy, Vol. 7, United Nations, Geneva, 1958, pp. 250-281. 
29. Rossini, F. D., K. S. Pitzer, R. L. Arnott, R. M. Brown and G. C. Pimental, Selected Values of Physical and Thermodynamic Properties of Hydrocarbons, Carnegic Press, Pittsburgh, 1953.

30. Powe11, R. W., R. A. Meyer, and R. G. Bourdeau, "Control of Radiation Effects in a Graphite Reactor Structure", Proceedings of the Second United Nations International Conference on the Peaceful Uses of Atomic Energy, Vol. 7, U.N. Geneva, 1958, pp. 282-294, also: Progress in Nuclear Energy, Series V, Metallurgy and Fuels, Vol. 4, Pergammon Press, London, 1961, 741-762.

31. Foreman, A. J. E., "On the Propagation of Thermal Waves in Media with Stored Energy," US/UK Graphite Conference, TID-7565 (Pt. 1), March 1959, pp. 115-120.

32. J. E. Brocklehurst, "The Irradiation Induced Creep of Graphite Under Accelerated Damage Produced by Boron Doping," Carbon, 13, 421 (1975).

33. Simmons, J. H. W., "The Effects of Neutron Irradiation on the Physical Properties of Graphite", Industrial Carbon and Graphite, Soc. Chem. Ind., London, 1958, pp. 511-517.

34. Snyder, W. A. and W. C. Riley, "Low Temperature Radiation Damage to Pile Grade Graphite", HW-35869, July 1955.

35. Riley, W. C., "Pile Material Evaluation of Experimental Graphites", $\mathrm{HW}-33705$, November 1954.

36. Helm, J. W. and J. M. Davidson, "Effect of Massive Neutron Exposure on the Distortion of Reactor Graphite", Carbon, 1, 435 (1964).

37. Simmons, J. H. W., "The Effects of Irradiation on the Mechanical Properties of Graphite," Proceedings of the Third Carbon Conference, Pergamon Press, London, 1959, pp. 559-568.

38. Morgan, W. C., "Notes on the Two-Phase Model for Radiation-Induced Dimensional Changes in Graphite", Carbon, 4, 215 (1966).

39. Barrington, E. P., A. L. Pope and J. S. Storg, "The Data in the Winfrith Nuclear Data Library", AEEW-R-4553, July 1963.

40. Daht, R. E. and H. H. Yoshikawa, "A Proposed Exposure Unit for Radiation-Damage Studies," Trans. Am. Nucl. Soc., I, 125 (1964).

41. Reed, D. L., "The Comparison of Carbon-Atom Displacement Rate in Graphite in the Dragon Reactor, The Petten HTR and Low Enrichment HTR", DP-559, Dragon Project, Winfrith, England, 1967. 
42. Perry, A. M., "Useful Life of Moderator Graphite," Molten-Salt Reactor Program Semi-annual Progress Report for Period Ending August 31, 1967. ORNL-4191, 1967, p. 84.

43. Reed, D. L., M. R. Everett, and R. Blackstone, "Correlation of Graphite Irradiations in the High-Flux Reactor Petten and in High-Temperature Reactors," Radiation Damage in Reactor Materials, Vol. 2, STI/PUB/230, International Atomic Energy Agency, Vienna, 1969, pp. 115-143. 


\section{DISTRIBUTION}

No. of

Copies

A. A. Churm

DOE Patent Group

$9800 \mathrm{~S}$. Cass Avenue

Argonne, IL 60439

2 DOE Technical Information Center

ONSITE

DOE Richiand Operations Office

H. E. Ransom

13 Hanford Engineering Development Laboratory

L. E. Kapinos

J. J. Muraoka (10)

R. E. Peterson

A. L. Trego

10 Pacific Northwest Laboratory

T. D. Chikalla

C. R. Hann/A. J. Haverfield

W. C. Morgan (2)

G. L. Tingey

Technical Information Files (3)

Publishing Coordination (2) 


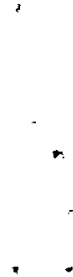

-

. 